\title{
INFLUENCE OF UV-C RADIATION ON THE MICROBIOLOGICAL PURITY IN SELECTED SPECIES OF HERBS
}

\section{WPŁYW PROMIENIOWANIA UV-C NA CZYSTOŚĆ MIKROBIOLOGICZNĄ WYBRANYCH GATUNKÓW ZIÓŁ}

\author{
Marta Jolanta Kozak-Kalita ${ }^{1(\mathrm{~B}, \mathrm{C}, \mathrm{E}, \mathrm{F})}$, Paweł Sobczak ${ }^{1(\mathrm{~A}, \mathrm{~B}, \mathrm{D}, \mathrm{E})}$, Kazimierz Zawiślak $^{1(\mathrm{~A})}$, \\ Jacek Mazur $^{1(\mathrm{~A}, \mathrm{~B}, \mathrm{E})}$, Marian Panasiewicz ${ }^{1(\mathrm{~A}, \mathrm{~B}, \mathrm{G})}$, Wioletta Agnieszka Żukiewicz-Sobczak ${ }^{2(\mathrm{~A}, \mathrm{~B}, \mathrm{C}, \mathrm{D})}$
}

\author{
${ }^{1}$ Department of Food Engineering and Machines, Faculty of Production Engineering, \\ University of Life Sciences in Lublin, Poland \\ ${ }^{2}$ Department of Health, Faculty of Health and Social Sciences, Pope John Paul II State \\ School of Higher Education in Biała Podlaska, Poland
}

Authors' contribution Wkład autorów: A. Study design/planning zaplanowanie badań B. Data collection/entry zebranie danych C. Data analysis/statistics dane - analiza i statystyki D. Data interpretation interpretacja danych E. Preparation of manuscript przygotowanie artykułu F. Literature analysis/search wyszukiwanie i analiza literatury G. Funds collection zebranie funduszy

\section{Summary}

Background. Herbs are used in both the food and pharmaceutical industry. The quality of products received from herbal raw materials depends primarily on the microbiological purity of herbs. The presence of germs in food products contributes to developing alimentary infections and to the contamination of food with mycotoxins. Decontamination with ultraviolet UV-C rays is a proven way to enhance the microbiological purity of food products as radiation directly affects the structure of the nucleic acid of living organisms and destroys them without selective biocidal activity. The aim of the study was to determine the microbiological purity of selected species of herbs and assess the possibility of using UV-C radiation to increase it.

Material and methods. The scope of work included the separation of three dimensional fractions of dried herbs such as thyme, medical cistus and stinging nettle, and then subjecting them to UV-C light and determining the total number of germs in the herbs with respect to the control sample, which consisted of untreated herbs.

Results. The tested herbs were characterised by diversified microbiological purity, depending on the species and a type of size fraction. Sterilisation of herbs with UV-C radiations allowed for increasing their microbiological purity as compared to the control sample, in the case of the fraction with the largest particle size by about 37\% - thyme, 73\% - cistus and 30\% - nettle. Conclusions. The use of UV-C radiation allowed for considerable reduction of the number of germs found in the examined herbs.

Keywords: UV-C sterilization, microbiological purity, thyme, medical cistus, stinging nettle

\section{Streszczenie}

Wprowadzenie. Zioła znajdują zastosowanie zarówno w przemyśle spożywczym jak i farmaceutycznym. Jakość produktów otrzymywanych z surowców zielarskich zależy przede wszystkim od czystości mikrobiologicznej ziół. Obecność drobnoustrojów w produktach żywnościowych przyczynia się do powstawania infekcji pokarmowych oraz skażenia mikotoksynami. Dekontaminacja przy pomocy promieni ultrafioletowych UV-C stanowi sprawdzony sposób zwiększenia czystości mikrobiologicznej produktów spożywczych, gdyż promieniowanie to bezpośrednio wpływa na strukturę kwasów nukleinowych organizmów żywych i niszczy je, przy czym nie wykazuje wybiórczej aktywności biobójczej. Celem pracy było określenie czystości mikrobiologicznej wybranych gatunków ziół i ocena możliwości wykorzystania promieniowania UV-C do jej zwiększenia.

Materiał i metody. Zakres pracy obejmował rozdzielenie na trzy frakcje wymiarowe suszonych ziół takich jak tymianek pospolity, czystek lekarski i pokrzywa zwyczajna, a następnie poddanie ich działaniu promieni UV-C i określenie ogólnej liczby drobnoustrojów w ziołach w odniesieniu do próby kontrolnej, którą stanowiły zioła nie poddane obróbce.

Wyniki. Badane zioła charakteryzowały się zróżnicowaną czystością mikrobiologiczną zależną od ich gatunku oraz rodzaju frakcji wymiarowej. Sterylizacja ziół promieniami UV-C umożliwiła zwiększenie ich czystości mikrobiologicznej w stosunku do próby kontrolnej, w przypadku frakcji o największym wymiarze cząstek odpowiednio o około 37\%- tymianek pospolity, 73\%-czystek lekarski i o 30\%- pokrzy wa zwyczajna.

Wnioski. Zastosowanie promieniowania UV-C pozwoliło w znaczący sposób zmniejszyć ilość drobnoustrojów obecnych w badanych ziołach.

Słowa kluczowe: sterylizacja UV-C, czystość mikrobiologiczna, tymianek pospolity, czystek lekarski, pokrzywa zwyczajna
Tables: 3

References: 26

Submitted: 2016 Dec 28

Accepted: 2017 Jan 05

Kozak-Kalita MJ, Sobczak P, Zawiślak K, Mazur J, Panasiewicz M, Żukiewicz-Sobczak WA. Influence of UV-C radiation on the microbiological purity in selected species of herbs. Health Prob Civil. 2018; 12(4): 285-290. https://doi.org/10.5114/hpc.2018.77838

Address for correspondence / Adres korespondencyjny: Wioletta Agnieszka Żukiewicz-Sobczak, Department of Health, Faculty of Health and Social Sciences, Pope John Paul II State School of Higher Education in Biala Podlaska, Sidorska 102, 21-500 Biała Podlaska, Poland, e-mail: wiola.zukiewiczsobczak@gmail.com, phone: +48 833449900

ORCID: Paweł Sobczak https://orcid.org/0000-0003-2167-1498, Wioletta Agnieszka Żukiewicz-Sobczak https://orcid.org/0000-0002-0142-5102

Copyright: (C) Pope John Paul II State School of Higher Education in Biała Podlaska, Marta Jolanta Kozak-Kalita, Paweł Sobczak, Kazimierz Zawiślak, Jacek Mazur, Marian Panasiewicz, Wioletta Agnieszka Żukiewicz-Sobczak. This is an Open Access journal, all articles are distributed under the terms of the Creative Commons Attribution-NonCommercial-ShareAlike 4.0 International (CC BY-NC-SA 4.0) License (http://creativecommons.org/licenses/by-nc-sa/4.0/), allowing third parties to copy and redistribute the material in any medium or format and to remix, transform, and build upon the material, provided the original work is properly cited and states its license. 


\section{Introduction}

Herbal raw materials are widely used in the food, pharmaceutical and cosmetic industries. Herbs can be used in the form of dried, whole or ground/shredded plant parts, their blends, essential oils, herbal extracts, or microcapsules. Because of their characteristic aromatic and preservative properties, they are used as natural agents for extending the shelf life of food and as spices [1, 2]. Herbs and herbal preparations are used in therapies assisting conventional medicine and are also components of food products belonging to the group of functional foods. Health-improving properties of herbal raw materials stem from the presence of biologically active compounds, including glycosides, flavonoids, alkaloids and essential oils. Herbs can, however, be significantly contaminated by diverse microflora [3-5].

Dried herbs have a low water content, which hinders the growth of germs and occurrence of undesirable chemical reactions. However, despite the presence of antibiotic substances and moisture content, which is unfavourable for most germs, they can be colonised by generically and quantitatively diversified microflora. The microbiological quality of herbs mainly depends on the part of the plant which yields raw herbal material, because the level of microbiological contamination results from the varying degree of contact between parts of the plant and the external environment during cultivation (primary factors), as well as their susceptibility to reinfection during further processing, storage or transport (secondary factors) [6-10]. Contamination of herbs with microorganisms can cause changes in their sensory characteristics, chemical composition, and also pose a danger for the health of consumers, because of the possible occurrence of mycotoxins and pathogens. As demonstrated by literature data, the degree of herb infection can be very high and the overall quantity of microorganisms in certain types of herbal raw materials can reach $10^{8} \mathrm{CFU} / \mathrm{g}$. The recommendations published in the Polish quality norms impose increasingly higher restrictions on the degree of microbiological contamination in herbs. These requirements include both the recommended and warning indicators pertaining to specific groups of microorganisms [8, 10-12].

Microbiological quality of herbal raw materials can be increased by providing adequate hygiene and sanitary conditions in the course of drying and grinding or shredding processes, as well as by storing them at the appropriate temperature. High microbiological contamination of herbal raw materials necessitates their decontamination. In addition to the well-known and long used methods such as e.g.: high temperature or chemical agents, a new and rapidly developing method of increasing product safety is provided by sterilization with UV-C radiation [13-15].

Sterilisation with ultraviolet UV radiation allows one to quickly and effectively neutralise microorganisms. UV radiation occurs naturally in nature as part of the solar light spectrum. The wavelength, intensity of its operation and distance from the source affects the properties of ultraviolet radiation. Sterilisation is conducted using high - energy UV-C rays and consist in treating microorganism cells with short 210-328 nm wavelength radiation which is lethal for microbes. UV-C radiation directly impacts the structure of nucleic acids in microorganisms and, as evidenced by tests, the most effective wavelength for inactivating microbes is the radiation band of $254 \mathrm{~nm}$. UV-C rays tear apart the links of DNA and RNA chains, thus destroying bacteria, fungi, moulds and other microorganisms. Moreover, UV-C rays cause denaturation of proteins in living organisms and inhibit the formation of suboxides and free radicals, which are also toxic to the cell [16].

At the beginning, the UV-C technology was only used in medicine to disinfect surgical instruments, but now it is also increasingly often applied in the food industry. It is a good solution in the case of products which cannot be treated with high temperatures. UV-C radiation would also work in conditions where humidity is increased, which encourages the reproduction of microorganisms in the air, on the machinery and equipment, as well as on the processed raw materials. Sterilisation with UV radiation is completely safe for humans. Moreover, its use provides additional protection for workers against microorganisms without negative impact on the environment. UV-C also allows for the reduction of unpleasant odours and extends the shelf life of food products $[17,18]$.

Appropriate selection of the irradiation dose allows for rapid elimination of more than $99 \%$ of harmful microorganisms, preventing them from reproducing, while ensuring a high level of safety for people and extension of the produced food durability. What is important, UV-C radiation does not show selective biocidal activity [16].

The aim of the study was to determine the microbiological purity of selected species of herbs and assess the possibility of using UV-C radiation to increase its degree. The scope of studies included exposure of dried herbs to UV-C rays in the sterilisation chamber for granular or ground/shredded materials (patent No W.125446) and quantitative indication of their microbiological purity as compared to the control sample. 


\title{
Material and methods
}

The research material comprised the following three types of dried herbs, sourced from herb processing plants located in Lublin Voivodeship, such as thyme (Thymus vulgaris), Cistus (Cistus ladaniferus) and stinging nettle (Urtica dioica L.). Using a laboratory AS 200 Retsch vibratory sieve shaker, raw materials were evaluated for granulometric size composition in accordance with the PN-R-64798:2009P norm, which enabled them to determine the average particle size and the degree of fragmentation. For this purpose, seven sieves with mesh size of $0.1 \mathrm{~mm}, 0.2 \mathrm{~mm}, 0.5$ $\mathrm{mm}, 1 \mathrm{~mm}, 2 \mathrm{~mm}, 3.15 \mathrm{~mm}, 4 \mathrm{~mm}$ were applied. Then, the herbs were separated into three fractions with a particle size of $<1 \mathrm{~mm}, 1-2 \mathrm{~mm}>2 \mathrm{~mm}$. The moisture content of particular herbs was estimated in accordance with the applicable standard (ISO 6496: 2002) [19] with the oven-drying method ( $\left.\mathrm{t}=105^{\circ} \mathrm{C}\right)$.

Dried herbs were sterilised with UV-C radiation in a sterilising chamber for granulated materials. The control sample comprised raw materials which had not undergone treatment. The device, in which herbs were sterilized has an air-tight housing with internal UV radiators, equipped with a power and control system with an irradiation time setting control, as well as a rack for the input material. In order to carry out sterilisation, a sample weighing $1 \mathrm{~g}$ was sourced and spread in a thin layer in the container for this material and then it was exposed to UV-C radiation for 60,120 and $180 \mathrm{~s}$. The container with the material was located at a distance of 20 $\mathrm{mm}$ from the UV lamp [20].

The quantitative determination of the microbiological purity of the dried herb was performed by using the plate method in accordance with the standard (BS EN ISO 4833:2004). The measurement was based on weighing a sample of $0.5 \mathrm{~g}$ and then transferring it to a $50 \mathrm{ml}$ sterile Falcon tube and filling it up with distilled water. Then, the sample was inoculated onto a plate with a standardised medium - agar and incubated at $32^{\circ} \mathrm{C}$ for 48 hours. After this time had expired the total number of microorganisms was counted [21]. The research was conducted at the Research Centres (EAT, CBNI) at the Pope John Paul II State School of Higher Education in Biała Podlaska. Sterilization and determination of the microbiological purity for each of the examined herb fractions was performed in three repetitions. The number of microorganisms was expressed as the colony forming units in $1 \mathrm{~g}$ of product ( $\mathrm{CFU} \mathrm{g}^{-1}$ ) and transposed into a logarithmic form (log CFU g ${ }^{-1}$ ).

\section{Results and discussion}

The research was conducted in accordance with the developed methodology. Table 1 shows the results of measuring the fragmentation of the dried herbs and in Figure 1 their sieve analysis is shown, which helped in determining the average particle size of the tested raw materials.

Table 1. Level of dried herbs fragmentation

\begin{tabular}{|c|c|}
\hline Raw material type & Level of fragmentation \\
\hline Thymus vulgaris & $1.045 \pm 0.0133$ \\
\hline Cistus & $1.876 \pm 0.0346$ \\
\hline Urtica & $0.8915 \pm 0.0711$ \\
\hline
\end{tabular}

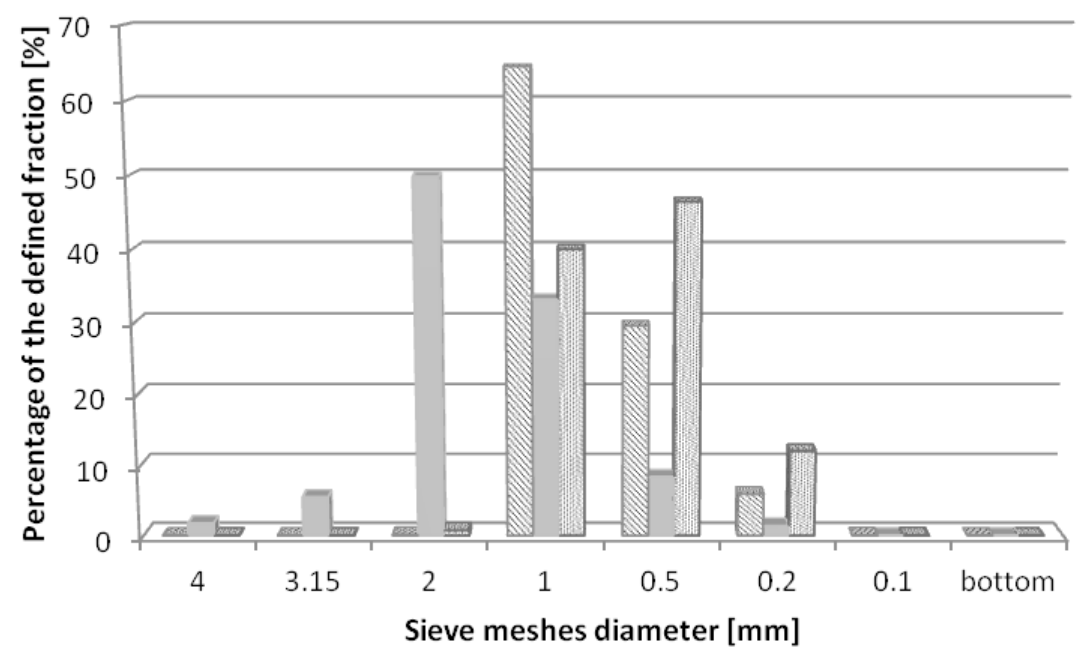

\author{
Common thyme \\ Cistus \\ 四 Stinging nettle
}

Figure 1. Sieve analysis of dried herbs - percentage participation of fraction on the sieves 
Dried herbs were characterised by varying degrees of fragmentation. The stinging nettle was the most fragmented, and the cistus had the largest particle size. The sieve analysis showed the common thyme to have more than $64 \%$ share in the $<1 \mathrm{~mm}$ fraction, the cistus almost $50 \%$ share in the $<2 \mathrm{~mm}$ fraction and the stinging nettle more than $46 \%$ share in the $<0.5 \mathrm{~mm}$ fraction. In the tested herbs, there did not occur fractions with a particle size below $0.2 \mathrm{~mm}$.

The measurement results of the moisture content of dried herbs are presented in Table 2.

Table 2. Moisture content of dried herbs depending on the fraction size

\begin{tabular}{|c|c|c|}
\hline Raw material type & Fraction size [mm] & Moisture content [\%] \\
\hline \multirow{3}{*}{ Thymus vulgaris } & $<1$ & $8.74 \pm 0.62$ \\
\cline { 2 - 3 } & $1-2$ & $8.40 \pm 0.52$ \\
\cline { 2 - 3 } & $>2$ & $7.96 \pm 1.31$ \\
\hline \multirow{3}{*}{ Cistus } & $<1$ & $10.06 \pm 0.27$ \\
\cline { 2 - 3 } & $1-2$ & $9.88 \pm 0.17$ \\
\cline { 2 - 3 } & $>2$ & $9.06 \pm 1.43$ \\
\hline \multirow{3}{*}{ Stinging nettle } & $<1$ & $9.44 \pm 1.21$ \\
\cline { 2 - 3 } & $1-2$ & $9.13 \pm 0.70$ \\
\cline { 2 - 3 } & $>2$ & $9.93 \pm 0.26$ \\
\hline
\end{tabular}

The tested herbal materials have similar moisture content of less than $14 \%$, which prevents the growth of mould [9]. The lowest moisture content is characteristic of thyme, and the highest one of cistus. Herb fractions with a particle size $>2 \mathrm{~mm}$ have lower moisture content compared to the finer fractions.

Table 3 shows the results of microbiological purity of the dried herbs, depending on their particle size and the duration of sterilization.

Table 3. Microbiological purity of dried herbs depending on the size fraction and the sterilization time

\begin{tabular}{|c|c|c|c|}
\hline Raw material type & Fraction size [mm] & Sterilisation time [s] & $\begin{array}{c}\text { Total number } \\
\text { of microorganisms } \\
{\left[\mathrm{CFU} \cdot \mathbf{g}^{-1}\right]}\end{array}$ \\
\hline \multirow{12}{*}{ Thymus vulgaris } & \multirow{4}{*}{$<1$} & 0 & UNC \\
\hline & & 60 & 490 \\
\hline & & 120 & 388 \\
\hline & & 180 & 220 \\
\hline & \multirow{4}{*}{$1-2$} & 0 & UNC \\
\hline & & 60 & 240 \\
\hline & & 120 & 250 \\
\hline & & 180 & 200 \\
\hline & \multirow{4}{*}{$>2$} & 0 & 400 \\
\hline & & 60 & 350 \\
\hline & & 120 & 264 \\
\hline & & 180 & 250 \\
\hline \multirow{12}{*}{ Cistus } & \multirow{4}{*}{$<1$} & 0 & UNC \\
\hline & & 60 & 150 \\
\hline & & 120 & 200 \\
\hline & & 180 & 150 \\
\hline & \multirow{4}{*}{$1-2$} & 0 & 250 \\
\hline & & 60 & 214 \\
\hline & & 120 & 210 \\
\hline & & 180 & 180 \\
\hline & \multirow{4}{*}{$>2$} & 0 & 300 \\
\hline & & 60 & 265 \\
\hline & & 120 & 200 \\
\hline & & 180 & 80 \\
\hline
\end{tabular}




\begin{tabular}{|c|c|c|c|}
\hline Raw material type & Fraction size $[\mathrm{mm}]$ & Sterilisation time [s] & $\begin{array}{c}\text { Total number } \\
\text { of microorganisms } \\
{\left[\mathrm{CFU} \cdot \mathrm{g}^{-1}\right]}\end{array}$ \\
\hline \multirow{12}{*}{ Urtica dioica } & \multirow{4}{*}{$<1$} & 0 & UNC + yeast \\
\hline & & 60 & $\mathrm{Npl}$ \\
\hline & & 120 & $\mathrm{Npl}$ \\
\hline & & 180 & 400 \\
\hline & \multirow{4}{*}{$1-2$} & 0 & UNC + yeast \\
\hline & & 60 & 380 \\
\hline & & 120 & 350 \\
\hline & & 180 & 350 \\
\hline & \multirow{4}{*}{$>2$} & 0 & UNC \\
\hline & & 60 & 400 \\
\hline & & 120 & 350 \\
\hline & & 180 & 350 \\
\hline
\end{tabular}

UNC (the uncountable colonies) $>500 \mathrm{CFU}$

The tested herbs were characterized by varying degrees of contamination, depending on the plant species and degree of fragmentation. The greatest number of microorganisms was determined in the smallest fractions of herbs - above $500 \mathrm{CFU}\left(>2.70 \log \mathrm{CFU} \mathrm{g}^{-1}\right)$.

The stinging nettle was characterized by a much higher degree of microbial contamination in comparison with other herb genera, which is associated with a different way of harvesting herbal raw materials in each case. In addition, research has shown the presence of yeast in stinging nettle fractions, with a particle size of $<1$ and 1-2 mm. The cistus and thyme were harvested on plantations, but the stinging nettle was obtained from natural stands, which could cause a reduction in the quality of the material obtained, because it was exposed to herbicides or cultivation treatments $[22,23]$.

The use of UV-C sterilisation allowed for reducing the number of microorganisms and removing the yeast present in herbs, when compared with the control sample. Extending the time of UV-C radiation operating on the studied herbs resulted in a significant reduction of the number of microorganisms present in all fractions of herbal raw materials. For example, in the case of the herbs with the greatest particle size, from 2.60 to 2.40 log $\mathrm{CFU} \mathrm{g}^{-1}$ for thyme, from 2.48 to $1.90 \log \mathrm{CFU} \mathrm{g}^{-1}$ for the cistus and above and 2.70 to $2.54 \log \mathrm{CFU} \mathrm{g}^{-1}$ for stinging nettle.

The results of the analyses performed by Wójcik-Stopczyńska et al. (2009) on the evaluation of microbiological purity of dried herbs offered on the Polish market by different manufacturers were similar. Research has shown that the total number of microorganisms in raw herbal material ranged from 1.76 to 6.19 log CFU g-1 depending on the species of the raw material [24]. Similar results were obtained by Aguilera et al. (2005), who, while studying the dried herb, marked the total micro-organism content from<1.0 to $6.0 \log \mathrm{CFU} \cdot \mathrm{g}^{-1}$ [25]. However, the studies of other authors indicate that in dried spices and herbs, the total number of bacteria reaches a higher level $\left(106-108 \mathrm{CFU} \cdot \mathrm{g}^{-1}\right)[12,26]$.

The comparison of the obtained results of research with the Polish standards (Farmakopea) and the guidelines of the International Commission on Microbiological Specifications for Foods (ICMSF) indicates that all the herbs investigated in this work are characterised by acceptable microbiological contamination $\left(10^{7} \mathrm{CFU}\right.$. $\mathrm{g}^{-1}$ or $\left.\mathrm{mL}\right)[8,26]$.

\section{Conclusions}

1. The smallest particle size was found in the stinging nettle, while the cistus had the largest particles.

2 . The moisture content of the studied herbal raw materials is below $14 \%$, which protects them from moulds.

3. Dried herbs showed diverse microbiological purity, where the cistus was the least contaminated one and the nettle had the finest particle size fraction, which may stem from a different way of harvesting these herbs.

4. Sterilisation by irradiation with UV-C for 3 minutes allows for a considerable reduction of the number of microorganisms present in herbs, in comparison with the control sample.

5. The use of a new device for UV-C sterilisation of granulated and finely fragmented materials can increase the microbiological purity of herbs, but one must perform further studies with extended duration of their sterilisation. 


\section{References:}

1. Craig WJ. Health-promoting properties of common herbs. Am J Clin Nutr. 1999; 70(Suppl): 491-499. https://doi.org/10.1093/ajcn/70.3.491s

2. Wasilewska M, Bergier J. Eating habits of adolescents in Poland and in other countries. Health Prob Civil. 2015; 9(4): 40-48. https://doi.org/10.5114/hpc.2015.57701

3. Kozak M, Sobczak P, Żukiewicz-Sobczak P. Health properties of selected herbal plants. Health Prob Civil. 2016; 10(2): 64-70. https://doi.org/10.5114/hpc.2016.59635

4. Tapsell LC, Hemphill I, Cobiac L, Sullivan DR, Fenech M. Health benefits of herbs and spices: the past, the present, the future. Med J Australia. 2006; 185(4): 1-24.

5. Kiczorowska B, Klebaniuk R, Bąkowski M, Al-Yasiry ARHM. Culinary herbs - the nutritive value and content of minerals. J Elem. 2015; 20(3): 599-608. https://doi.org/10.5601/jelem.2014.19.4.739

6. Czech E, Kneifel W, Kopp B. Microbiological status of commercially available medicinal herbal drugs a screening study. Planta Med. 2001; 1: 263-269. https://doi.org/10.1055/s-2001-12007

7. Dudkiewicz J, Krysińska-Traczyk E, Skórska C, Sitkowska J, Prażmo Z, Golec M. Exposure to airborne microorganisms and endotoxin in herbs processing plants. Ann Agric Environ Med. 2001; 8: 201-211.

8. Urząd Rejestracji Produktów Leczniczych, Wyrobów Medycznych i Produktów Biobójczych. Farmakopea Polska Wyd. VII, Suppl. Warszawa: Polskie Towarzystwo Farmaceutyczne; 2007 (in Polish).

9. Kunicka-Styczyńska A, Śmigielski K. Microbiological safety of herbal raw materials. Przemysł Spożywczy. 2011; 6: 50-53 (in Polish).

10. Martins HM, Martins ML, Dias MI, Bernardo F. Evaluation of microbiological quality of medicinal plants used in natural infusions. Int. J. Food Microbiol. 2001; 68(Pt 1-2): 149-153. https://doi.org/10.1016/S0168-1605(01)00480-9

11. Steinka I, Misiewicz Ł, Kukułowicz A, Ćwikliński M, Dmowski P, Sznajdrowska A. An attempt to assess the microbiological quality of selected dried plants used as stimulants and nutrients with healing properties. ZNAMG. 2011; 68: 13-20 (in Polish).

12. Wójcik-Stopczyńska B, Jakubowska B, Jadczak D. Microbiological quality of some fresh herbs. ZPPNR. 2009; 539: 773-780 (in Polish).

13. Brodowska A, Śmigielski K. Comparison of methods of herbs and spice decontamination. Chemik. 2014; 2(68): 97-102 (in Polish).

14. Przetaczek-Rożnowska I, Kuźniak M. Source of microbiological contamination of medicinal herbs and condiments and methods of decontamination. Post. Fitoter. 2016; 1: 59-62 (in Polish).

15. Remiszewski M, Kulczak M, Jeżewska M, Korbas E, Czajkowska D. Effect of decontamination with the use of steam on the quality of selected spices. Żywność, Nauka, Technologia, Jakość. 2006; 3(48): 23-34.

16. Sterylizacja UVC [Internet]. Chorzów: Weindich S.J. [cited 2016 Nov 30]. Available from: http://sterylizacja.net/ (in Polish).

17. inter arma [Internet]. Rudawa: Inter Arma Sp. z. o.o. Sterylizacja UV-C [cited 2016 Dec 01]. Available from: http://interarma.pl/sterylizacja-uvc/ (in Polish).

18. mieso.com.pl [Internet]. Racibórz: Miesięcznik Rzeźnik Polski. Sterylizacja UVC w produkcji żywności [cited 2016 Nov 30]. Available from: http://mieso.com.pl/?p=854 (in Polish).

19. PN-ISO 6496:2002. Pasze - Oznaczanie wilgotności i zawartości innych substancji lotnych (in Polish).

20. Komora do sterylizacji materiałów ziarnistych lub rozdrobnionych. Patent application No. W.125446. Polish Patent Office; 2016 (in Polish).

21. PN-EN ISO 4833:2004. Mikrobiologia żywności i pasz - Horyzontalna metoda oznaczania liczby drobnoustrojów - Metoda płytkowa w temperaturze 30 stopni C (in Polish).

22. Buchwald W, Mordalski R, Kucharski W. The cultivation of herbal plants in Poland. Agrotechnika. 2011; 1: 28-31 (in Polish).

23. Sadowski A. Uprawa ziół i możliwości ich wykorzystania. Białystok: Sekretariat Regionalny Krajowej Sieci Obszarów Wiejskich w województwie podlaskim; 2013 (in Polish).

24. Wójcik-Stopczyńska B, Jakubowska B, Reichelt M. Microbiological contamination of dried culinary herbs. Herba Pol. 2009; 55(3): 206-213.

25. Aguilera MO, Stagnitta PV, Micalizzi B, Stefanini de Guzman AM. Prevalence and characterization of Clostridium perfringens from spices in Argentina. Anaerobe. 2005; 11: 327-34. https://doi.org/10.1016/j.anaerobe.2005.05.003

26. Banerjee M, Sarkar PK. Microbiological quality of some retail spices in India. Food Res Int. 2003; 36: $469-74$. https://doi.org/10.1016/S0963-9969(02)00194-1 